\title{
Considerations to Rearrange the Value Chain
}

\author{
Prof. Dr. Günter Hofbauer \\ Technische Hochschule Ingolstadt, Business School \\ Esplanade 10, 85049 Ingolstadt, Germany \\ Anita Sangl \\ Technische Hochschule Ingolstadt, Business School \\ Esplanade 10, 85049 Ingolstadt, Germany
}

\begin{abstract}
Purpose of the article: The basic research question of this paper is to consider how to rearrange the value chain after having served 35 years as a helpful management concept. The primary activities are revised and will be rearranged after careful considerations. Methodology: This scientific approach is analytical and conceptual. First, we derive on the analytical basis of statistical data the relevance for value creation. Second, the theoretical and conceptual approach is providing a systematic overview on the activities under research of a contemporary value driven company. Scientific aim: The scientific aim of this article is about rethinking of the primary activities of the value chain. The requirement of integrating a new activity and taking out another primary activity is explained and based on analytical and conceptual considerations. Findings: Organizations, processes and business models are changing rapidly. This leads to changes in business operations on a large scale. Procurement for example is not any more just the supporting ordering department. Procurement has changed into a value creator. On the other side logistic activities should not be regarded as primary activities anymore, because there is no value added by inbound nor outbound logistics. Conclusions: This article reconsiders the value chain under contemporary conditions in the age of Industry 4.0 to achieve competitive advantage. The first conclusion is to consider procurement not any more as a secondary activity, but as a primary activity, because procurement has the highest impact on the cost position of a product. The second conclusion is that the logistic activities were identified not to be regarded as a primary activitie any more. They should be integrated into the secondary activities, because the value add is insignificant.
\end{abstract}

Keywords: value, primary activities, competitive advantage, procurement, cost position, logistics

\section{INTRODUCTION}

Over the last two decades we have come to recognize that companies, business models, operations, processes and all other business related activities are changing and transforming in a very fast and irresistible way. The existing value chain has been a well-known model and conception of classification and arrangement of the activities of a company for many years. As time changes, reality changes and the management literature has to keep up with the time.

The initial point of advisement was the changing role of procurement. Primarily dedicated as a secondary activity [19]. But during the last couple of years the role of procurement has changed significantly $[6,7]$.

Products, their performance and particularly the price, which a company offers to its customers are mainly determined by procurement activities combined with the adequate level of successful vertical supplier integration [9]. 
In addition to that inbound and outbound logistic activities do not have the capability to create value. In times of automated and sensor controlled supply, reduced inventory through just in time and just in sequence procedures, premanufactured modules and systems and supply chains across companies, there is hardly to find some value to add to the value of the product by logistic activities.

\section{METHODOLOGY}

The basic underlying question is, how a company can transform business inputs into business outputs and create value, which is higher than the cost of creating that output. This value added is the margin.

\section{Margin = Value Created and Captured minus Cost of Creating that Value}

According to Porter competitive advantage can be built, when a company earns profit by creating and offering value. Providing more value to the customers means building up a higher competitive advantage. So the critical issues under research should be first the value creating (primary) activities.

The methodology is derived from the above outlined question of research. So the considerations concentrate primarily on value creation. The applied methods are derived from the methodology and most appropriate seems to be a statistical analysis with facts and figures completed with conceptual considerations.

This article is divided into three parts: Firstly the initial situation will be shown. Secondly the problems will be formulated and criticism will be explained. Thirdly the findings will be provided and a proposal will be given to cover all critical issues.

\section{INITIAL SITUATION}

Porter proposed a general-purpose model of the value [19], which can be used by companies to examine the activities of a company. The value chain is a set of business activities, which a company carries out in order to create value for its customers. The way in which these activities are carried out determines the cost and value proposition and in the long run affects the profitability of a company. The value chain helps managers to understand from what sources value is driven.

Porter's value chain is one of the most cited management approaches of the last decades. In the well-known value chain model (Figure 1) the value activities are split into primary activities and support activities. 


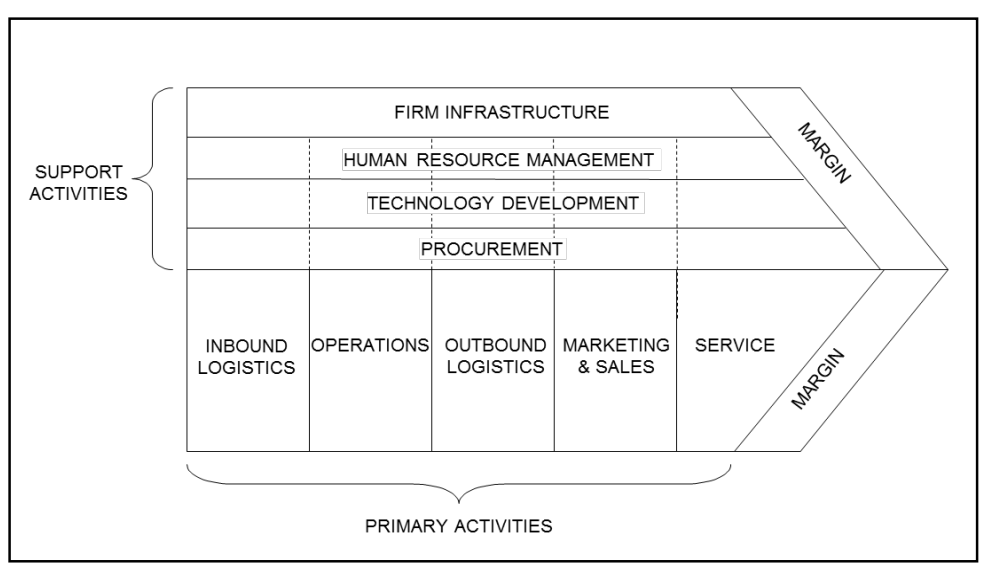

Figure 1: The Generic Value Chain. Source: [2].

Following Porter, primary activities relate directly to the physical creation of a product. Those primary activities consist of:

Inbound logistics: these activities are related to receiving and storing as well as the internal distribution of inputs, such as warehousing, material handling, inventory control, vehicle control and returns to suppliers.

Operations: the operational system creates value in transforming the inputs into outputs, which can be sold to customers. In order to get the final product form, various activities have to be carried out like machining, assembly, testing, printing, packaging and facility operations.

Outbound logistics: with these activities the company's products are delivered to the customers. These activities include storage, warehousing, material handling, collection and physical distribution of products to buyers, delivery vehicle operations, order processing and scheduling.

Marketing and Sales: these activities are essential to get customers, willing to buy the company's products rather than competitor's products. All activities associated with providing goods to customers and inducing them to do so like advertising, sales force, channel management and pricing are included here.

Service: These activities concentrate on enhancing or maintaining the value of the product, such as product adjustment, installation, repair, training and spare parts supply.

According to Porter's statement, procurement -in the context of the value chain- is one of the so called supporting activities. Even though the purchased goods are usually linked with primary activities, they are also part of any value creating activity including supporting activities and are spread within the entire chain of a company.

To be considered as one of the primary activities, an activity has to be involved in the physical creation of the products, its sale and transfer to the buyer or in the products aftersales assistance and have to be clearly assigned [20]. In the contemporary practice procurement can be recognized of being involved right from the very early beginning into the development and sourcing process [5]. Thus we can suggest, that through careful selection of (development) suppliers, production materials and manufacturing processes also the procurement activity takes over a significant role to a product's concept and so to its physical creation and value generation. 
Porter recognizes indeed the value contribution of procurement departments for companies. According to Porter the cost proportion of procurement activities are usually quite low or even a negligible portion of total costs [20]. But nowadays in a contemporary application of procurement, the sourcing activities have a huge impact on the company's overall costs, quality, innovativeness and its differentiation. So improved purchasing and procurement activities can strongly affect the cost and value proposition. Furthermore they have also a lasting effect on other activities, which continue to use the inputs and interact with the suppliers.

\section{PROBLEM FORMULATION AND CRITICISM}

The value chain displays the different steps of accumulating value of a product in a structured process of activities. These activities use resources and these are linked to each other. The characteristic of primary activities is that they are creating value, this means that they initiate more value than the cost of these activities. Within this logic the secondary activities use resources without creating value, nevertheless they are important enablers of the primary activities. In this chapter some problems arising with the dated value chain will be discussed. The theses of this article are formulated as follows:

1. If it is verified that procurement creates value, it has accordingly to be treated as a primary activity.

2. If logistic activities do not create value, then they have to be characterized as secondary activities.

\section{Consideration of Procurement as a Value Creator}

The evolution from purchasing to procurement forms the scientific basis for this paper. In former times the operational buying execution was recognized as an assisting activity for other managerial functions within the value chain of a company. Since the end of the 1980s, when the competitive potential of procurement was emerging, the matter and meaning of procurement is subject to constant change $[16,6]$.

This leads to the first basic research question of this paper, which is to identify the impact of procurement in creating value.

Undoubtedly procurement is meanwhile of pivotal importance in the value chain of a company and contributes to value creation within the value chain of a company [10]. This becomes clear, if we take a deeper look into a typical cost structure. The cost breakdown for the automotive industry shows in Figure 2 exemplarily that the value of the sourced material reaches nearly $50 \%$ of the gross production value. Further on the share of trading goods (18.8\%) is quite high. This manifests the close link between OEMs and their suppliers, who have taken over complete production chains through the various outsourcing processes over the last couple of years [17].

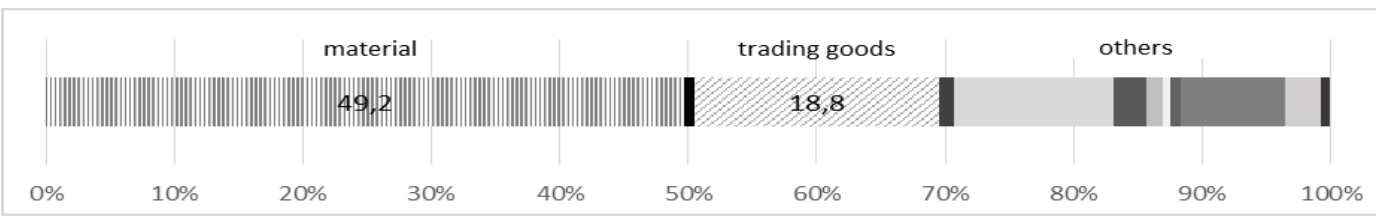

Figure 2: Cost structure automotive industry (2013). Source: own graph, based on [21].

This change is particularly due to the ongoing and increasing concentration on core competencies of the OEMs and as a consequence thereof the reduction of steps in the production process as well as on different research and development levels. Instead of producing all the required parts and components by their own, they were more and more sourced from subcontractors, which can produce those parts and modules often more 
economically.

This transition of procurement was increasing over the time line. At the very beginning the purchasing department had to buy parts at the lowest price. The main task was cost optimization. The next step was the introduction of a structured process within the company in order to execute the buying process in the most efficient way. After this process optimization the procurement focused on the suppliers. The scope was to combine the value chains of the suppliers with the interface of the own supply chain of the company. The scope was to improve the performance of suppliers and to avoid discontinuities in the supply chains. The latest step was the integration management. The suppliers have to be integrated into various activities over the whole value chain [11].

Market saturation, decrease in prices and margins as well as increasing competitive pressure enforced the turnaround away from classical purchasing towards a modern and strategic oriented procurement management $[6,14]$ and will rise new scientific challenges.

Some enterprises already recognize the leverage effect of procurement. In 2015 a survey of BAK Basel Economics and Deloitte among nearly 400 enterprises in the Swiss Mechanical and Electrical Engineering Industries underlines the great importance of procurement activities: $60 \%$ indicate, that optimizing and increasing the efficiency of the procurement chain will play a dominating role to enhance efficiency and achieve substantial cost reduction [1].

The enhanced importance of procurement for creating value can be illustrated by a numerical example of the volume. According to the German Federal Statistical Office (2015) the share of material costs in the chemical and engineering industry were above $50 \%$ and for the automotive industry even exceeded two thirds of all costs.

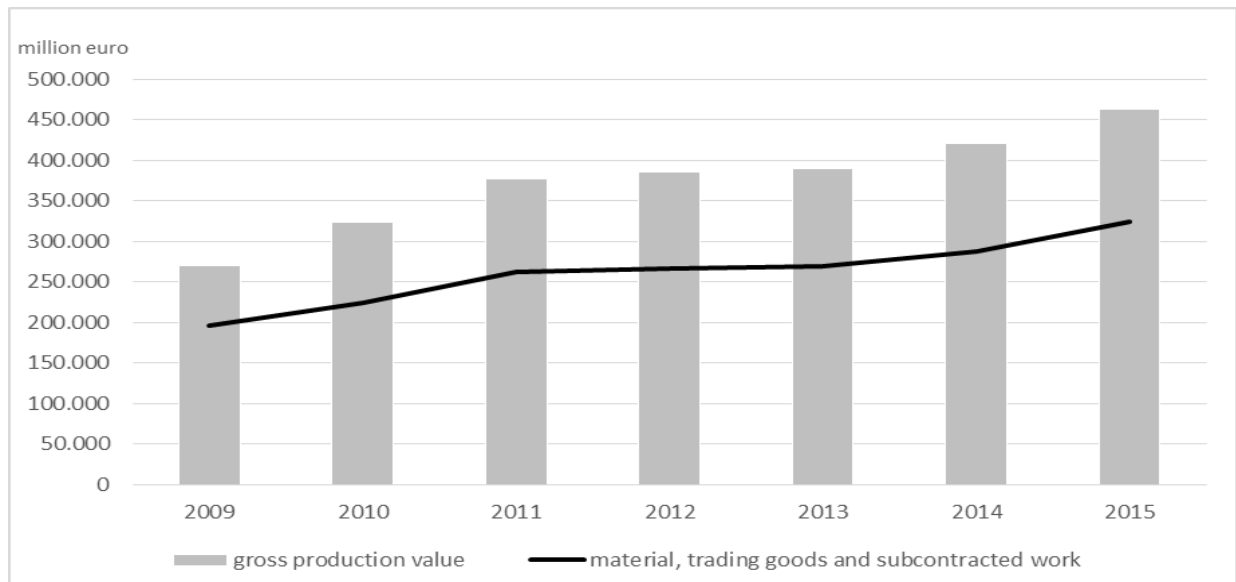

Figure 3: Evolution of gross production value and costs for sourced parts and material. Source: own graph, based on [21].

Figure 3 shows the evolution of costs for material, trading goods and subcontracted work for the automotive industry, one of the most important sectors in Germany. Since 2009 the share is on a constantly high level and even exceeds two thirds. So the major lever to optimize a company's cost position is the position of sourced parts and material costs.

The importance and the impact of contemporary procurement was already shown and argued in other publications [10]. 


\section{Objectives of procurement}

Procurement represents the interface between companies and sourcing markets. Procurement can contribute to competitive advantage and the objectives of procurement can be derived from the relevant entrepreneurial objectives $[6,8,13,12,15]$.

As material costs have a direct impact on a firm's profitability, cost objectives have a remarkable importance. A meaningful example underlines this statement: a decrease of material costs of only 3\% causes the same impact on profit as an increase in sales of $60 \%$ (assumptions: calculatory expected return 3\%, share of costs of materials 60\%) [23]. But to avoid the danger of incompatibility and mutually negative influences, cost targets have to be considered in total with all other objectives of a company.

The quality of bought-in parts is another important objective for procurement. To ensure continuous production, reliable supply with raw material and other bought-in parts, modules and systems is indispensable. Last but not least the increasing flexibility is a procurement objective as well $[13,14]$.

\section{Tools of procurement}

In terms of advanced procurement the most important issue is to detect and utilize innovations and innovative potential from outside for the company. Therefore an extensive market research is necessary. Once suppliers are identified, they should be closely involved into the OEM's pre serial and serial development process. Further on products will only be designed best for subsequent manufacturing at supplier's site, if their manufacturing know-how is considered prematurely during the product development process. Far too often products were designed and physically developed before the production feasibility is checked, which is necessarily the next step [4].

According to Kerkhoff, companies, which do not seize the opportunity of early material and supplier decisions, will suffer from strategic disadvantages [14]. Companies need to change their thinking, they have to get off from reactive procurement execution towards proactive procurement management. In doing this, the main task is to secure a close alignment with the sourcing market. There is a very early possibility to set the course in doing the right decisions for the parts, modules and systems for a perfect fit of the subsequent production process. Differences and variations to the original technical specifications or vague requirements can result quite fast in uncontrollable higher expenses. Such inaccurate conditions will directly influence the return of the product and accordingly will have an impact on the value chain. In this case value of the company will be destroyed. The task of the procurement department is to create competitive advantage, this means to assure a stringent supplier management on the one hand and to ascertain an internal regulating factor on the other hand.

In order to support value creation in terms of the return of the products, the procurement management has to look for innovations and solutions to reduce complexity and optimize the product for the whole value chain.

Cost engineering is one key method to analyze processes, find further value improvements and run the product development and production management process efficiently. Purchasing prices should not be negotiated without being analyzed bottom up with all effecting factors. Cost engineering aims to create transparency, to open up different options and to find a balance between function, performance and costs as well as prices. However it requires a great deal of experience and technical expertise to calculate the overall cost of a product, which is not yet existing. Only technical drawings and facts out of specification sheets are available. 
The main task of the procurement management is, to find the best supplier with an optimized cost position in order to create more value [4].

In consideration of the outlined statements, based on empirical data and analytical remarks, the thesis can be established that procurement has a large and multiple potential to create value, accordingly it has to be treated as a primary activity.

\section{Considering Logistic Efforts as Secondary Activities}

With regard to the logistic activities there are obvious reasons to consider to remove these activities from the primary activities, because they do not add value to the product. Inbound logistic activities like receiving, storing and distributing of input factors are quite necessary. The main question is, whether there is a value added. If not, this activity should be reclassified as secondary activity. However, an increase in value does not occur and therefore this activity should be reclassified as secondary activity. The same reasoning applies to the outbound activities. Storage, collection and distribution is quite necessary as well, but value added in these activities is also hardly to find.

It is evident, that the relevance of these activities declines in times of Industry 4.0 with automated supporting processes and sensor controlled internal supply as well as external supply chains across companies and means of transport. These processes are highly automated, but the management attention on creating value has shifted. The proportion of logistics costs of total costs is declining as can be seen from the graph for industry shown below (Figure 4). This suggests that the potential for cost savings through automation is very low and already largely exhausted.

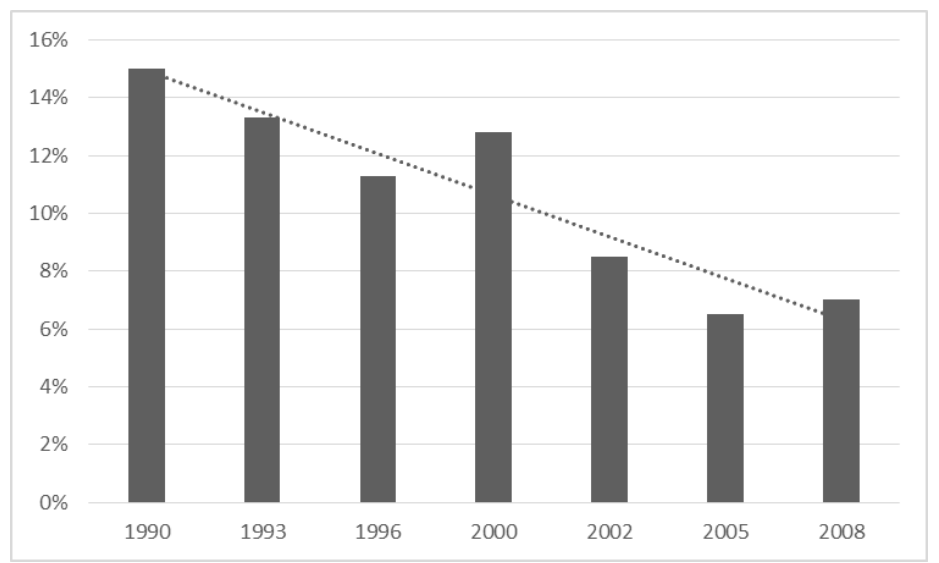

Figure 4:Evolution of logistics costs. Source: own graph, based on [3].

This leads to the second basic research question of this paper, which is to identify the value creating potential of logistic activities. If there is no potential, they should be classified as supporting and secondary activities.

Since many years we know about efficient principles in production technology. Taiichi Ohno (1978), head of production at Toyota applied the term MUDA, which was introduced and translated with 'waste' in the English literature [18]. But this is not the whole meaning of this term. Ohno evaluated activities with regard to the additional value of the activity. And so 'waste' it is not exactly what he means, because the opposite of waste is parsimony. The opposite of 'MUDA' however is usefulness, meaningfulness, feasibility or effectiveness and these phrases hit exactly the spot. Therefor a better expression should be used as unnecessary effort or needless operating expense. The elimination of these unnecessary efforts is one of the 
most effective ways to increase profitability. In order to do this, it is important to understand what is unnecessary and where it comes up. For the value of the customer it makes no difference where, by whom or how often a part of a product, or even a product has been received, stapled, collected or stored. No value added can be recognized.

There are seven kinds of unnecessary activities: transportation, inventory, overproduction, waiting, over-processing, defects and motion. The first 3 of them can directly be related with the value chain concept. It can be concluded, that it is required, but not necessary to create value. With interrelated, sensor controlled and process optimized Industry 4.0 standard, there will be the opportunity to optimize these issues on a huge scale. Industry 4.0 is able to link processes so that one operation after the other can be executed in an optimized way and reduce transportation, inventory and overproduction.

Transportation of products between process steps, to the storage or to the customer causes cost, but adds no value to the product. In addition excessive transportation and handling increase the possibility of quality deterioration and damages. Transportation also means inbound and outbound logistics. Of course it can be difficult to reduce transportation activities, because to some extent transportation is inevitable, but does not add value.

Inventory increases when more products are produced than sold to customers, it directly results from overproduction. Unnecessary inventory occupies productive floor space, increases lead times and covers problems in the production process. By achieving a seamless workflow in the production it is possible to optimize the lead times, to raise efficiency in using the capacity and to decrease inventory with related cost.

Overproduction means that a product is manufactured before it is actually required. Overproduction is highly expensive for a company, because resources are occupied, storage increases and capital commitment goes up. The Toyota production system overcame this problem by introducing the Just-In-Time (JIT) principle, where each part was delivered and/or manufactured just as it was needed.

The share of logistic costs in total for industry was about 7.0\% (as already shown in Figure 4) in 2008. But $28 \%$ of industrial companies surveyed do not know their logistic costs in detail [22], which makes more obvious a certain potential of unnecessary effort.

Logistic costs are primarily driven by rising energy, fuel and transport prices as well as high personnel expenses. The detailed composition of the logistic costs ( $7 \%$ of total cost) is shown in Figure 5.

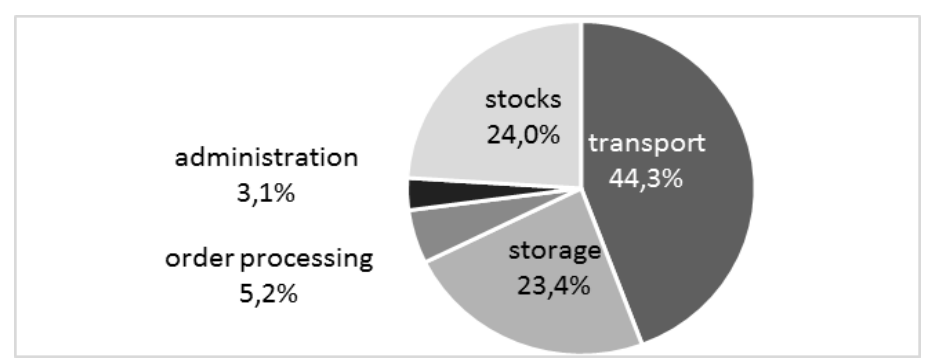

Figure 5: Composition of logistic costs. Source: own graph, based on [2].

The possible build-up of stocks due to increasing bottlenecks in the road transport sector and the increasing environmental protection and safety requirements could lead to an increase in logistic costs in the future. The decoupling of transports resulting from the construction of 
higher inventories follows the demand for reliability in the logistic systems [22], but at the same time represents a needless operating expense as already described above.

For the sake of completeness, here the remaining 4 kinds of activities, which should be avoided, too:

Waiting occurs when products or parts are not flowing or being processed. There is a huge amount of lead time wasted for waiting for the next production step. This occurs, because material flow is not optimized, production runs are very long and machines respectively work centers are not interlinked.

Over-Processing means to establish high-performing processes and to use expensive high precision production equipment when simpler working steps and tools would be sufficient. The crucial thing is, that high precision tools, as soon as they are available, they have to be used in order to get a return on that investment.

Defects cause a lot of cost for a company. So this is a very important issue to be solved, because it means capacity loss and raising of manufacturing cost. Quality operations are supporting to solve these problems.

Motion is related to transport and waiting and even solve arising problems when they occur. Reaching, walking, lifting and stretching are some motions, which could occur. With these motions problems, mistakes and damages may occur. These obvious causes for troubles should be analyzed and redesigned.

In consideration of the outlined statements in this chapter, based on empirical data and analytical remarks, the thesis can be established that logistic activities have vanishingly small impact on value creation. It's in the nature of things that supporting activities should be characterized as secondary activities in the value chain.

\section{FINDINGS AND PROPOSITION TO REARRANGE THE VALUE CHAIN}

In this article the primary activities are focused and their value creating characteristic should be outlined. The approach was twofold: Should a new activity be incorporated into the primary activities and/or should an established activity be removed from the primary activities? In order to meet this point different arguments have been discussed in chapter 3 .

The most important issue is to incorporate procurement into the primary activities and consider logistic activities as supporting activities. The basic reasoning is the value creating characteristic, which was pointed out in chapter 3.1 and 3.2 .

Thesis 1 examined whether procurement has the potential to create value. The outcome is, that this activity has changed and is able to contribute to the value added. Accordingly it has to be treated as primary activity.

Thesis 2 argued about the value contribution of logistic activities. As a result it can be stated, that nowadays the importance of these activities have decreased. Thus they have to be characterized as secondary activities.

\section{CONCLUSION}

Competitive advantages are necessary prerequisites of a valuable company. For the sake of profitability it is essential to know about the value chain and the various contributions to the 
value added. It is also needed to know about value annihilating activities. The value chain is a reasonable concept for managers to analyze valuable activities and in the long run to transform these activities into competitive advantage.

The first proposal to rearrange the value chain is to incorporate the procurement activity into the primary activities. The explanations in the statements show, why this change is mandatory, well-founded and science-based. Excellent companies have realized that procurement is more than just buying at the best price. Procurement activities have to be applied as forward sourcing in the very early stage of development. Only in this early stage innovations can be put into practice and design-to-cost and value-to-cost considerations can be taken into account in order to create and raise value across the whole value chain. So it is necessary to analyze and use the potential of the sourcing markets as early as possible. Further on it is essential to select and use high-performance suppliers to gain competitive advantage.

The second proposal is to remove the logistic activities from the primary activities and include them into the supporting activities, because they do not have potential to add value to the product. Inbound logistic activities like receiving, storing and distributing of input factors are quite necessary, but should be reclassified as secondary activity. The same reasoning applies to the outbound activities, storage, collection and distribution is quite necessary as well, but these activities do not really add value to the product.

\section{References}

Deloitte, BAK Basel Economics. (2015). Welche Strategien zur Effizienzsteigerung und Kostenreduktion werden für Sie in den nächsten 12 Monaten im Vordergrund stehen? Retrieved from http://de.statista.com/statistik/daten/studie/485844/umfrage/strategien-zur-effizienzsteigerung-undkostenreduktion-schweizer-mem-unternehmen.

Fraunhofer (Fraunhofer SCS) (2014). Aufteilung der Logistikkosten in Europa im Jahr 2014 nach Kostenstellen. In Statista - Das Statistik-Portal. Retrieved from https://de.statista.com/statistik/daten/studie/72704/umfrage/verteilung-der-logistikkosten-in-europa/.

Handelsblatt (2009). Anteil der Logistikkosten an den Gesamtkosten in Industrie und Handel von 1990 bis 2008. In Statista - Das Statistik-Portal. Retrieved from https://de.statista.com/statistik/daten/studie /6346/umfrage/anteil-der-logistikkosten-an-den-gesamtkosten/.

Hecht, D. (2014). Modernes Beschaffungsmanagement in Lehre und Praxis. Berlin: uni-edition.

Hecht, D., Goldbach, J. (2017). Modernes Beschaffungsmanagement in Lehre und Praxis. In: Hofbauer, G. (Ed.), Technische Beschaffung, pp. 211-234, Berlin: uni-edition.

Hofbauer, G. (2017). Technische Beschaffung. Berlin: uni-edition.

Hofbauer, G., Bauer, Ch. (2004). Integriertes Beschaffungsmarketing - Der systematische Ansatz im Wertschöpfungsprozess. München: Verlag Vahlen.

Hofbauer, G., Hecht, D. (2017). Procurement 2025: Die Zukunft der Beschaffung. Berlin: uni-edition.

Hofbauer, G., Mashhour, T., Fischer, M. (2016). Lieferantenmanagement. Die wertorientierte Gestaltung der Lieferbeziehung, 3rd edition, München: Oldenbourg.

Hofbauer, G., Sangl, A. (2017). Effective Procurement and Integration Management as a Basis for Value Creation. In: Hofbauer, G. (Ed.), Technische Beschaffung. Berlin: uni-edition, pp. 253-262.

Hofbauer, Günter; Sangl, Anita (2016). The Role of Procurement in Creating Value. In: Iveta Simberova, Ondej Zizlavsky und Frantisek Milichovsky (Hg.): Smart and Efficient Economy: Preparation for the Future Innovative Economy. 21st International Scientific Conference. Proceeding of Selected Papers. ICEM International Scientific Conference Economics and Management. Brno, Czech Republic, 19.-20.05.2016. Brno University of Technology, Faculty of Business and Management. Brno: University of Technology, Faculty of Business and Management, pp. 550-556.

Hofbauer, Günter (2013). Technisches Beschaffungsmanagement: Der Beschaffungsprozess. In: Hofbauer, Günter, Markt- und wertorientierte Unternehmensführung. Berlin: uni-edition, p. 258. 
Janker, C. G. (2004). Multivariate Lieferantenbewertung. Empirisch gestützte Konzeption eines anforderungsgerechten Bewertungssystems. Wiesbaden: Gabler.

Kerkhoff, G. (2008). Milliardengrab Einkauf: Einkauf - die Top-Verantwortung des Unternehmers nicht nur in schwierigen Zeiten (2nd ed). Weinheim: WILEY-VCH. Retrieved from http://deposit.d-nb.de/cgibin/dokserv?id=2973556\&prov=M\&dok_var=1\&dok_ext=htm

Koppelmann, U. (2004). Beschaffungsmarketing. Berlin [u.a.]: Springer.

Lingohr, T., Kruschel, M. (2011). Best Practices im Value Management. Wie Sie durch Einkauf und Technik einen nachhaltigen Wertbeitrag leisten können. Wiesbaden: Gabler.

Mönnig, A. (2014). Die Automobilindustrie - Das Nadelöhr zur Mobilität der Zukunft, Update April 2014.: gws Themenreport 14/03. Retrieved from http://www.gws-os.com/discussionpapers/tr_auto_14-03.pdf

Ohno, T. (1988). TOYOTA Production System, Beyond Large-Scale Production, CRC Press.

Porter, M.E. (1985). Competitive Advantage. New York: Free Press.

Porter, M. E. (2004). Competitive advantage: Creating and sustaining superior performance (1. Free Press export ed.). New York, NY: Free Press.

Statistisches Bundesamt (2015). Produzierendes Gewerbe. Kostenstruktur der Unternehmen des Verarbeitenden Gewerbes sowie des Bergbaus und der Gewinnung von Steinen und Erden. Retrieved from https://www.destatis.de/DE/Publikationen/Thematisch/IndustrieVerarbeitendesGewerbe/Strukturdaten/Koste nstruktur2040430137004.pdf?_blob=publicationFile

Straube, F., Pfohl, H.-C. (Ed.) (2008). Trends und Strategien in der Logistik. Globale Netzwerke im Wandel. BVL Bundesvereinigung Logistik. Hamburg: DVV Media Group Dt. Verkehrs-Verlag.

Wildemann, H. (2008). Einkaufspotentialanalyse: Programme zur partnerschaftlichen Erschließung von Rationalisierungspotentialen. München: TCW Transfer-Centrum-Verlag. 